Illinois State University

ISU ReD: Research and eData

Theses and Dissertations

3-29-2018

\title{
The Impact of Mentoring At-risk Youth on the Socialization Process of Pre-Service Teachers
}

Theresa Allgaier

Illinois State University, allgaier_24@hotmail.com

Follow this and additional works at: https://ir.library.illinoisstate.edu/etd

Part of the Curriculum and Instruction Commons, Educational Methods Commons, and the Other Education Commons

\section{Recommended Citation}

Allgaier, Theresa, "The Impact of Mentoring At-risk Youth on the Socialization Process of Pre-Service Teachers" (2018). Theses and Dissertations. 836.

https://ir.library.illinoisstate.edu/etd/836

This Thesis is brought to you for free and open access by ISU ReD: Research and eData. It has been accepted for inclusion in Theses and Dissertations by an authorized administrator of ISU ReD: Research and eData. For more information, please contact ISUReD@ilstu.edu. 


\section{THE IMPACT OF MENTORING AT-RISK YOUTH ON THE SOCIALIZATION PROCESS OF PRE-SERVICE TEACHERS}

Theresa Allgaier

60 Pages

While much is known about how traditional field based practical experiences in teacher preparation programs impact the socialization of pre-service teachers, less is known about how practical experiences within after-school programs and other contexts influence pre-service teacher socialization. Relatedly, many scholars have sought to understand at-risk youth and have investigated teachers' experiences with these students within the context of schools and the gym. The purpose of this study was to understand how mentoring at-risk youth in an after-school program impacted the socialization of six pre-service teachers. Occupational Socialization Theory provided the theoretical framework for this study. Six PETE majors, in their first year of the PETE program participated in the study which occurred concurrently with their involvement in the after-school program. Data sources included four semi-structured interviews with each participant and four critical incident accounts. Findings indicated that the PSTs described three important outcomes resulting from working as mentors to at-risk youth in the after-school program. First, PSTs discussed the significance of having additional practical experience teaching and how this furthered their teacher development. PSTs also described an impassioned appreciation for knowing students. Finally, as a result of mentoring at-risk children, PSTs felt an overwhelming personal responsibility to demonstrate healthy social and emotional behaviors. This provides further insights into the degree to which pre-service teachers are active agents in 
constructing their own conceptions of teaching through the dialectical nature of socialization. The experiences and knowledge gained by the pre-service teachers in this study served to construct a view of teaching that includes a strong emphasis on knowledge of students and focus on affective skill development. Consistent with previous literature, the importance of practical experiences to pre-service teachers like the one in this study may facilitate pre-service teachers in moving toward a focus on students earlier in teacher training programs.

KEYWORDS: Mentoring; Pre-service teachers; At-risk youth; PETE programs; Teacher socialization; After-school programs 


\title{
THE IMPACT OF MENTORING AT-RISK YOUTH ON THE SOCIALIZATION PROCESS OF PRE-SERVICE TEACHERS
}

THERESA ALLGAIER

\author{
A Thesis Submitted in Partial \\ Fulfillment of the Requirements \\ for the Degree of \\ MASTER OF SCIENCE
}

School of Kinesiology and Recreation

ILLINOIS STATE UNIVERSITY 
Copyright 2018 Theresa Allgaier 


\section{THE IMPACT OF MENTORING AT-RISK YOUTH ON THE SOCIALIZATION PROCESS OF PRE-SERVICE TEACHERS}

THERESA ALLGAIER

COMMITTEE MEMBERS:

Karen Gaudreault, Chair

Mary Henninger

Emily Jones 


\section{ACKNOWLEDGMENTS}

I would like to acknowledge and thank all those who helped me with their valuable support during the entire process of writing my thesis and throughout the advancement of my education.

Foremost, I want to express my sincere gratitude to my advisor Dr. Karen Gaudreault. She brought me on this new journey to Illinois State University to explore and finish my thesis alongside her. I cannot express my appreciation for her continued support, patience, and guidance. She has set an example of excellence as a researcher, mentor, instructor, and role model. I also want to thank her husband and children, who have brought me in like family and I am truly grateful for them. In addition, I would like to thank the other members of my committee, Dr. Mary Henninger and Dr. Emily Jones for all of their guidance through this process; support, ideas, and feedback have been absolutely invaluable.

I would especially like to thank my amazing family for their love, support, and constant encouragement through these two years. In particular, I would like to thank my wonderful parents for the continued support and wanting what was best for me. I appreciate everything you have done for me. Also, thank you to my sister, brother-in-law, Chloe, Keegan, and Carter. You encouraged me along the way and kept me sane with all the phone calls. I certainly could not have done this without any of you.

I would also like to thank my significant other, Chris. You have helped me greatly along the way, with your support, advice, and encouragement. I thank you for always being that person to listen and pick me back up. 
Finally, I want to acknowledge my mentee child from Healthy Pokes, Erin Chavis. The experiences I had with her and mentoring, created this idea for my thesis. She has helped me become a better mentor and I am so lucky to have her in my life. She is truly incredible.

I am sincerely appreciative of everyone who has helped and guided me along the way. I could not have done this without you all!

T. A. 


\section{CONTENTS}

Page

ACKNOWLEDGMENTS

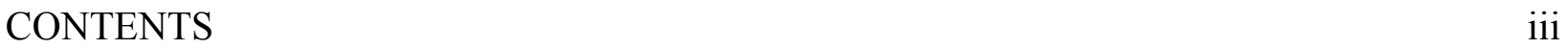

CHAPTER I: THE IMPACT OF MENTORING AT-RISK YOUTH ON THE

SOCIALIZATION PROCESS OF PRE-SERVICE TEACHERS 1

$\begin{array}{ll}\text { Introduction } & 1\end{array}$

Teacher Socialization $\quad 1$

PETE Programs 2

After-school Programs 3

$\begin{array}{ll}\text { Mentoring } & 4\end{array}$

$\begin{array}{ll}\text { Theoretical Framework } & 5\end{array}$

$\begin{array}{ll}\text { Purpose Statement and Research Questions } & 8\end{array}$

$\begin{array}{ll}\text { Method } & 8\end{array}$

$\begin{array}{ll}\text { Participants and Recruitment } & 8\end{array}$

$\begin{array}{ll}\text { The ASP } & 11\end{array}$

$\begin{array}{ll}\text { Data Collection } & 13\end{array}$

Role of the Researcher $\quad 15$

$\begin{array}{ll}\text { Researcher Subjectivities } & 15\end{array}$

$\begin{array}{ll}\text { Data Analysis } & 16\end{array}$

$\begin{array}{ll}\text { Trustworthiness } & 17\end{array}$

$\begin{array}{ll}\text { Findings } & 18\end{array}$

Additional Practical Experiences Developed Comfort and Confidence 18 
Relationships and In-depth Knowledge of Children 19

Internalization of the Obligation to Model Healthy Social-Emotional Behaviors 21

$\begin{array}{ll}\text { Discussion } & 23\end{array}$

$\begin{array}{ll}\text { Acculturation } & 23\end{array}$

$\begin{array}{ll}\text { Professional Socialization } & 25\end{array}$

$\begin{array}{ll}\text { Implications for PETE Programs } & 27\end{array}$

CHAPTER II: EXTENDED LITERATURE REVIEW 30

Occupational Socialization Theory 30

$\begin{array}{ll}\text { Acculturation } & 30\end{array}$

Professional Socialization $\quad 32$

$\begin{array}{ll}\text { Organizational Socialization } & 33\end{array}$

PETE Programs 36

$\begin{array}{ll}\text { Service Learning Experiences } & 37\end{array}$

$\begin{array}{ll}\text { After-school Programs } & 38\end{array}$

$\begin{array}{ll}\text { Mentoring } & 41\end{array}$

$\begin{array}{ll}\text { Conclusion } & 43\end{array}$

$\begin{array}{ll}\text { REFERENCES } & 45\end{array}$

APPENDIX A: INTERVIEW GUIDES

APPENDIX B: CRITICAL INCIDENT PROMPTS 60 


\section{CHAPTER I: THE IMPACT OF MENTORING AT-RISK YOUTH ON THE}

\section{SOCIALIZATION PROCESS OF PRE-SERVICE TEACHERS}

\section{Introduction}

Each individual is shaped by their own personal experiences. Teachers experience learning and teaching differently. Socialization into teaching is influenced by multiple factors within and through contextually bound social constructs Richards (2015) and Templin and Schempp (1989) described teacher socialization as a dynamic process. Over the last four decades, scholars have investigated how physical educators come to choose the profession of teaching, how teacher education programs impact pre-service teachers, and how induction into the profession shapes teachers' beliefs and dispositions toward the profession (Curtner-Smith, 2001; Lawson, 1983; Richards, 2015; Richards, Templin, \& Graber, 2014; Schempp \& Graber, 1992; Stroot, 1993; Templin \& Richards, 2014; Templin \& Schempp, 1989). Teacher Socialization Theory (Lawson, 1983; Richards, Templin, \& Graber, 2014) offers that socialization is defined by three different phases: acculturation, professional socialization, and organizational socialization.

Experiences individuals may have during their undergraduate PETE program can include service learning opportunities, on-site laboratory teaching, and student teaching. Some of the socializing factors within these experiences are socio-cultural and psychological. A teacher's socialization will be shaped based on the experiences they have, particularly during their PETE program.

\section{Teacher Socialization}

Teachers are engaged in the socialization process throughout their careers. The induction phase (years 1-3), however, provides additional unique challenges, as new teachers are 
unfamiliar with cultural norms of schools and other varying socializing agents in which they encounter (Curtner-Smith, 2001). Scholars have repeatedly argued for the need for PETE programs to include learning experiences that have the potential to prepare PSTs for the induction phase and to challenge the social norms that provide obstacles to their development (Richards, Templin, \& Gaudreault, 2013). As PSTs are going through their PETE program, they should be made aware of the potential challenges they might face in the school setting as a teacher if PETE programs are to fully prepare PSTs for the dynamic political context in schools.

Templin and Schempp (1989) describe teacher socialization as a dynamic process. The study of teacher socialization in education has been studied since the 1930s. Over the last four decades, the knowledge about the socialization of physical education (PE) teachers specifically, has been studied. The socialization process in PE is defined by three different phases, which include acculturation, professionalism socialization, and organizational socialization. These relate to the development of their careers as a PE teacher. There have been different socializing agents that have been identified that potentially influence the socialization of a teacher.

\section{PETE Programs}

Many scholars have examined ways for PETE programs to be effective and how to best prepare PSTs. It has also been mentioned that PETE programs should attend and address the developmental needs of PSTs (Kagan, 1992). These needs may consist of more procedural, rather than theoretical knowledge. Often times, PETE programs put a strong emphasis on PSTs mastery of procedural routines rather than having a balance between pedagogical teaching skills and the intellectual demands. Grossman (1992) provided criticism for this approach. Scholars have stated that knowing the PSTs in your program, the beliefs and attributes they bring, and 
acculturation experiences will assist in constructing meaningful experiences during the program (Feiman-Nemser \& Remillard, 1996; Graber, Killian, \& Woods, 2017).

It is well documented that field experiences within PETE programs are essential to teacher training (Behets \& Vergauwen, 2006). Field experiences and student teaching is crucial for PSTs because the students and teachers are socializing agents who have a significant influence on the beliefs the PSTs develop about teaching (Graber, Killian, \& Woods, 2017). These practical experiences also allow PSTs to develop reflective skills and professional knowledge by being reflective of their own teaching (Behets \& Vergauwen, 2006).

Further, scholars have determined that PSTs concerns progress through developmental phases throughout practical field experiences (Behets, 1990). They first focus on themselves, then as they become more comfortable they begin to focus on the act of teaching. That includes all of the pedagogical teaching skills. Finally, after those skills are developed, the PSTs are able to focus on students and student learning.

\section{After-school Programs}

Some PETE programs include experiences within the context of after-school programming for pre-service teachers as a way to interact with children and practice delivering PE content. ASPs can provide children the opportunity to increase positive youth development and additional physical activity (PA), in order to reach the minimum recommendations of 60 minutes a day (U.S. Department of Human Health Services (USDHHS), 2016). These programs have become more available for youth to engage in as supplementary opportunities to accumulate PA outside of school hours. Many programs have different objectives, such as tutoring clubs, reading and language clubs, etc. Academic learning, social/personal skills, and PA are outcomes that have been supported in recent research (Beighle, Morgan, Masurier, \& 
Pangrazi, 2006; Durlak, Weissberg, Pachan, 2010; Vandell et al., 2006). ASPs act as a source to assist youth within a supportive environment, allowing them to stay out of trouble (Pittman, Irby, Tolma, Yohalem, \& Ferber, 2003). Youth may find themselves taking part in unhealthy behaviors such as drugs and alcohol, violence, and sexual or unwanted behaviors. Mahoney, Larson, and Eccles (2005) found that among youth, the probability of positive youth development increases in the result of an ASPs resource. There is limited research looking at PA focused ASPs that have included mentorship. Consequently, future studies should be conducted to determine if findings related to mentorship have a significant impact on youth development, directly concerning their PA levels.

\section{Mentoring}

Mentoring is a widely-used developmental and intervention strategy used in various organizations (Baugh \& Sullivan, 2005). In the context of schools, mentoring is utilized to improve academic achievement and positive youth development. Positive youth development looks at progressing constructive characteristics and qualities of the "whole" child. Certain programs use the mentoring strategy in attempt to promote and foster different constructs of the individual. Objectives that are needing to be met are associated with functioning areas of youth which include: social, emotional, cognitive, behavioral, and moral competencies (Catalano, Berglund, Ryan, Lonczak, \& Hawkins, 2004). Hence, the role of a mentor is one who provides support and guidance for an individual in his or her personal, academic, and other functioning areas of life. Mentoring is often included in diverse settings within the school. Mentorship is one method to enhance positive experiences for youth and facilitate learning and growth (Gordon, Downey, \& Bangert, 2013). Playing an integral part in as a "buddy" who provides tutoring, 
guidance, and support in programs, such as ASPs. There are numerous factors that may play a substantial role in the mentoring relationship.

Many studies have been conducted that examine the effectiveness of mentoring programs and how mentoring impacts the mentee (Allen, 2007; Beltman \& Schaeben, 2012; Bozionelos, 2003; Chun, Sosik, \& Yun, 2012; Ghosh, Reio Jr., 2013). Subsequently, little research has been conducted examining the specific effects or outcomes that mentors gain from the mentoring experience. The surrounding literature reviewing the impact that mentorship has had on mentors themselves is frequently seen conducted within the workforce. Overall, the effects or outcomes of mentoring-type relationships for the mentors equate to the feeling of achievement, satisfaction, and confidence (Beltman \& Schaeben, 2012; Ghosh \& Reio Jr., 2013; Hunt \& Michael, 1984; O’Shea, Harwood, Kervin, \& Humphry, 2013). Therefore, this proposed study aims to investigate how being a mentor influences pre-service teachers' perceptions of teaching, and PE.

\section{Theoretical Framework}

Occupational Socialization Theory (OST) (Lawson, 1986) provided the theoretical framework for this study. Lawson (1986) describes occupational socialization as, "All of the kinds of socialization that initially influence persons to enter the field of physical education and that later are responsible for their perceptions and actions as teacher educators" (p. 107). In broader terms, OST is individuals' viewpoints on certain experiences that occur within the context of teaching. This theory has been used in the examination of the ways individuals come to acquire the beliefs, views, and dispositions associated with being a physical educator in K-12 schools. OST has been analyzed in other domains and occupations, however, Lortie (1975) was 
one who built research on teacher socialization in general education. Lawson (1983) took Lortie (1975) construct and exclusively researched teacher socialization in the realm of PE.

OST posits three distinct phases of the socialization process: acculturation, professional socialization, and organizational socialization. Acculturation is the time in which the potential teacher recruits learn about the profession through experiences as students in K-12 schools. A recruit is an individual whom is considering a profession which might be to become a physical educator but has yet to start a PETE program. Lawson (1983) suggests some key socializing agents within this context are experiences they personally had in PE class. Each recruit of a PETE program enters with perceptions and opinions on their "slate" with the idea of teaching PE. These preexisting perceptions are a construct known as subjective warrants. Subjective warrants influence the acculturation phase, which influences their idea of becoming a physical educator. Individuals have their own personal experiences from previous teachers and their behaviors; these create personal perceptions about what a PE teacher might look like and do. This pre-training stage is found to be an important factor in whether the pre-service teachers will implement the ideologies of their PETE programs.

Professional socialization is the second phase. This is when the individual is involved in formal teacher training in a PETE program. At this point, the individual(s) are considered PSTs. Personal experiences in K-12 PE is compared to the models and practices taught in the PETE program (Richards, Gaudreault, \& Templin, 2014). During this phase, PSTs are taught knowledge and pedagogy of effective teaching in PE. This pre-service training phase includes all learning experiences PSTs face throughout their PETE program. Professional socialization is noted to be the weakest part of socialization (Stran \& Curtner-Smith, 2009). Usually, during the PETE program, PSTs are not aware of organizational challenges that they might face when 
entering their teaching careers. Although the PSTs are exposed to specific skills during the program, it is often found that they will go back to the old ways of teaching as they experienced in their K-12 PE. Often, PSTs tend to emulate the physical educators they had as teachers rather than what they are being taught in the PETE program (Curtner-Smith, 1999). Usually, individual's subjective warrants have perspectives that do not align with the emphasis on their PETE program. PSTs insist on relying on the information that aligns more towards their beliefs and past experiences (Curtner-Smith, 2009). Challenges occur with the different beliefs each individual enters the program with and how the program shapes PSTs.

The final phase is identified as organizational socialization. Individuals enter this phase the first year they accept an official teaching job at a school. It was determined by Stroot and Ko (2006) that the first three years of this stage is the most significant. This phase occurs on the job in the context of schools. More importantly, it is the understanding of challenges being faced with different aspects of work (Richards, Templin, \& Gaudreault, 2013). Induction teachers face specific challenges in their first few years with this transition. These may influence the teachers' demeanor and the way they fulfill their responsibilities as a teacher. The transition between the professional and organization stage can be a struggle with adjusting to their new roles. New teachers may feel they cannot handle certain concerns such as attending meetings, inadequate time to prepare for lessons, and completing paperwork. These are challenges that induction teachers face in the school culture that they did not have exposure to in the PETE programs. The experiences PSTs encountered during particularly the professional socialization phase is closely connected to how the new teachers will react in their new job. PETE programs need to provide those PSTs with unique learning experiences as well as prepare them for realities in the workplace in order to have a successful induction phase. 


\section{Purpose Statement and Research Questions}

The purpose of the study was to investigate the influence of engaging in service learning in an after-school program and mentoring at-risk youth on the socialization process of PSTs. Research questions guiding this study was: (a) how do PSTs describe their experiences as a student in K-12 PE? (b) how do PSTs describe their experiences while going through the PETE program? (c) how do PSTs describe their experiences in the after-school program and how it is shaping their beliefs? (d) how do PSTs describe their mentoring experiences in the after-school program?

\section{Method}

\section{Participants and Recruitment}

Participants in this study included six PSTs, between the ages of 22 and 33 years old, who were enrolled in a PETE program in a rural Mountain West University. This convenience sample was 100\% Caucasian and included three males and three females. Each of the participants were in their first year of the PETE program in the same cohort. Prior to entering the PETE program, all six participants had transferred from a community college within the rural area where they completed general studies coursework. Only one of the participants described herself as being the athletic student in PE when younger. The other participants described themselves as different or even the overweight student. For example, Larry said, "When I was in third or fourth grade, I was kind of obese; overweight I guess" (Larry, Interview \#1). Cody expressed similar history by saying: "I was a bigger kid growing up" (Cody, Interview \#1).

\section{Acculturation experiences.}

The PSTs in this study described their personal experiences in K-12 PE as "fun". However, based on what they had already been learning from the PETE program, some noticed 
that their personal experiences did not necessarily align with best teaching practices. For example, Larry mentioned:

According to what I've learned so far through [the PETE program], I feel like my K-12 program was not very good. When I was in school there wasn't anything wrong with what we were doing, but now looking back I understand that it wasn't the best use of time just playing games and stuff. (Larry, Interview \#1)

A few participants described experiences, particularly from secondary level to be "roll out the ball". Some of them thought back to the activities they were taught. Some mentioned they practiced different skills and did a variety of units as others experienced just playing games. Two of the six participants had positive experiences all throughout. However, the majority of them described them having a negative PE experience. For example, Cody said, "I enjoyed it, the problem was I was bullied in the locker room a lot, so it kind of persuaded me from staying in PE” (Cody, Interview \#1).

\section{Reasons for entering profession.}

The personal experiences each participant had during their acculturation phase influenced their decision to become physical educators. Whether they wanted to emulate positive experiences for other children or provide students a totally different experience than they had. For example, Mary discussed, “It's like how I was taught, I don't want to teach like that. I don't want kids to experience it the way that I was taught because it was kind of traumatizing for some." She continued to describe it being difficult for students were not as strong or confident in weight class because they were always being compared to others.

Another reason participants mentioned for becoming a physical educator was to work with children and help them become physically literate individuals and to live healthy lifestyles. 
Participants also wanted to be seen as a role model for students in this position. This was a key characteristic the participants indicated that physical educators need to acquire. David discussed "I think teachers need to want to be a role model, they want to be a leader for the students to help them out" (David, Interview \#1). Larry felt similar in that teacher should be, "A good role model to the students, they need to feel like they can talk with the teacher" (Larry, Interview \#1). Some participants described their PE teachers to be a role model for them as K-12 learners. These role model teachers were part of influencing this career choice. For example, Beth said, "I always looked up to [my PE teachers and coaches], in like all the aspects and I was hoping one day I could have someone, like my students look up to me; like a role model kind of thing" (Beth, Interview \#4). Finally, all of the participants entered the PETE program with a teacher orientation opposed to coaching. Although each of them expressed an interest in coaching in the future, their first priority was becoming a physical educator.

Before the recruitment of participants for this study, IRB approval was obtained through the university. No data was collected prior to attaining IRB approval. The six participants of this study were members of the ASP in the previous semester. A service learning project in a class in the PETE program was coordinated with the ASP. These participants were selected for this study due to availability, participation/mentorship during the ASP, and position within the PETE program. The individuals were recruited electronically with an email cordially asking for their participation. Along with the recruitment, each provided informed consent to participate, which included tape-recording for the interviews. The confidentiality of the participants in relation to the information shared was maintained. The information remained anonymous and protected by using pseudonyms. 


\section{The ASP}

The ASP was a multi-disciplinary, longitudinal after-school enrichment program for atrisk youth and a service learning project within a PETE program in which PSTs gained professional experience through mentorship and delivering physical activity lessons. The enrolled approximately 31 children ages 6 to 14-year-olds (1st to 8 th grade) and ran for 12weeks during each academic semester; with children participating in one 2-hour session per week. During these sessions, children received education and participated in activities focused on physical activity, nutrition, and behavioral health. In addition, each child was mentored by a college student working in the program.

Each child was carefully matched with college student role model. University faculty supervisors and graduate student coordinators carefully observed the children and college students' interaction during the first one to two sessions of the program. In many cases, each child naturally connected with a particular college student. When this happened, the mentor/mentee pairing was, in essence, self-selected. In the event that this did not occur, program staff consulted with school personnel in order to pair the children with an appropriate college student mentor. The adult mentors for this program were all college-aged students from the university, with specialties in a variety of disciplines. Most mentors were future educators or nutrition/dieticians.

The mentoring program of the ASP served to foster relationships and build a trusting connection between each mentor and mentee. The mentors' role in the program was to positively engage with the children through the course of the program. The adult mentor's duties consisted of motivating and encouraging children to remain engaged in the activities, as well as continue to be physically active during the ASP sessions. Relationships were developed throughout the 
program by initiating healthy connections and interactions with the children on a weekly basis. In addition to participating with their mentee during weekly program sessions, mentors visited their mentee at school once a week to nurture the relationship further and to make a connection "outside the gym".

Work in the ASP was a required component of a content course within the university PETE program. As a part of this service learning program, all of the PSTs enrolled in the content course completed service learning hours within the ASP and were provided the opportunity to self-select different roles and responsibilities. These included: mentoring, data collection, snack materials and supplies, pedometer calibration, and nutrition lesson instruction. Each student selected the role they would fulfill based on their interests, abilities, and desired commitment. In addition to service learning hours, each student in the course completed a teaching assignment in which they independently led and facilitated structured physical activity lessons from the ASP curriculum.

The PSTs in this study were purposefully selected according to the following criteria: enrollment in the PETE program, enrolled in the content course, self-selected mentoring role within the ASP, and willingness to participate in the study. The PSTs in this study occupied two different roles concurrently during this study: teacher and mentor. Over the course of the program, the PSTs independently taught a varying number of 30-minute lessons to the ASP group based on their self-selected role/job within the ASP as a part of their service-learning assignment for the course (Beth, 2; Marianna, 4; Darren, 5; Cody, 7; Larry, 7; Mary, 14). Each PST chose which lesson they wanted to teach and delivered this lesson during its scheduled place within the scope and sequence of the ASP curriculum. These lessons consisted of physical activity and nutrition content within the ASP curriculum. When they were responsible for lead 
teaching a lesson, their mentee participated in the activity with other children and mentors. The PSTs independently delivered the lesson including instructions, demonstrations, classroom management, feedback, and closure for the entire ASP.

As their second role, these participants mentored an at-risk child who participated in the ASP. The children were considered at-risk based on different factors such as "BMI in the 85 th percentile for sex and age, unhealthy family-lifestyle habits, demonstrated sedentary behavior, low parental income, poor behavioral control or high emotional distress, low parental involvement, or other medical conditions that contributed to poor, overall health" (Gaudreault, Shiver, Kinder, \& Guseman, 2016). Participants mentored their child throughout this entire program. Mentoring consisted of participating in the lessons and interacting during the program with the child. Three of the six participants in this study also visited their mentee once a week for an hour at school as part of mentoring responsibilities associated with the ASP.

\section{Data Collection}

Data sources included four individual face-to-face interviews with each participant and four critical incident reports generated by the primary researcher. These were aligned with the tenets of OST and the four research questions.

\section{Interviews.}

The primary data source was individual interviews (see Appendix A). Interviews were conducted with each of the participants and followed a semi-structured interview guide designed to gather rich data about the participants' perceptions through questions about the participants' feelings, views, and beliefs about mentoring and becoming a teacher (Patton, 2015). Semistructured interview questions are also referred to as open-ended questions. Potentially, having flexibility within the interview will allow the interviewer to respond and explore answers from 
the participants. The interview guides were generated by the primary researcher using the process of OST.

All participants were interviewed four times throughout the 12-week program. These interviews occurred weeks three, six, nine, and twelve of the program. Interviews were conducted by either the primary researcher or faculty advisor in an office for privacy and each lasted approximately 30 minutes in duration. The four interview guides were created based on the teacher socialization literature. Each guide was specifically focused on one of the research questions which linked with the acculturation and professional socialization stages of teacher socialization. The first interview question was related to research question one about their own personal experiences they had as a student in PE. The second interview correlated with research question two, which was describing their experiences during the PETE program at that time. The third interview was about their overall experiences with the ASP and how they felt it was helping them as a teacher. Finally, interview four was related to the last research question about their thoughts and experiences with mentoring and they perceived this as socialization. All interviews were audio recorded and transcribed verbatim for analysis.

\section{Critical incident accounts.}

Secondly, PSTs participating in this study completed a series of critical incident accounts (Tripp, 1993). This tool is useful in minimizing negative attributes of anecdotes and effectively turns anecdotes into data (FitzGerald, Dent, Seale, Kerins, \& McElvaney, 2008). Each account was given the week of each interview (see Appendix B). The participants were given one week to complete each prompt and did so independently electronically. The researchers emailed the critical incident account prompt to the participants with instructions to write as much as they could and to go into as much detail as possible in response to each prompt. The PSTs typed their 
responses within the word document provided and submitted their response via email to the researcher. Prompts correlated with the three stages of the OST and research questions, similar to the interviews. The two stages of OST that the accounts were focused towards were acculturation and professional socialization.

\section{Role of the Researcher}

The researcher collected, interpreted, and analyzed the data for this study. The role of the researcher was acting as a researcher-participant since the researcher was also the Volunteer Program Coordinator for the ASP program. The researcher oversaw all the mentors for this program. This position allowed the researcher to be directly connected with the participants of the program and their behaviors. Prior to the study, the researcher was working as the Volunteer Program Coordinator position for one semester. The responsibility of this position included matching up the mentors with a child, overseeing their responsibilities and duties such as visiting their child at school and attendance, and lastly, scheduling the teaching lessons.

\section{Researcher Subjectivities}

There were a variety of researcher subjectivities that were addressed. The primary researcher had former participation with the program as the mentor coordinator and as a mentor. The researcher was a recent graduate of the undergraduate PETE program. The coursework, experiences, and participation as a student in the program gave the researcher a biased view of the impact of mentoring. Years prior, the researcher took part of the mentor role for an individual child for two years of the program. Having personal experience as a mentor allowed for a better understanding of the mentor role and how it connected to teacher preparation. The relationship between the researcher and mentee was positive and long-lasting. During the time of the research, the previous mentee, who the researcher had mentored continued to be part of the ASP. 
The researcher had formed thoughts about mentoring an at-risk child in the program. Although the ASP incorporated four different aspects, the primary one being PA, the researcher viewed mentoring as one of the most important parts because of the personal experience in that role.

Secondly, the researcher worked directly with all the mentors in the program. The participants in the study had connected with the researcher the semester before conducting the study in other aspects of the PETE program such as supervising and guest lectures. Relationships were formed and developed with each individual/participant while working with them in the previous semester during the PETE program and ASP. Having established those relationships prior to conducting this research was helpful during the interview process to allow more comfort in expressing their feelings and sharing their experiences. The subjectivities presented above are items the researcher recognized to be influenced and biased towards the significance of the mentoring experiences, but by acknowledging them allows the reader to understand the role that the researcher had for this study.

\section{Data Analysis}

All interviews were audio recorded and transcribed verbatim. All data sources (interview transcripts and critical incident accounts) were analyzed inductively using elements of grounded theory and constant comparison (Glaser, 2017). First, data were read and initial consistencies in participants' expressions were noted. Following this, the researcher engaged in open coding where passages were provided a code or label that best captured the participants' expression. Next, codes were aggregated and organized into categories. Then, categories were reviewed and examined within and between one another using constant comparison. Through this process, themes were identified and refined. Finally, in order to fully answer the research questions and fulfill the purpose of the study, all data and themes were considered relative to OST (Lawson, 
1986). To ensure the confidentiality of the participants, the data was only viewed by the research team. The team included the primary researcher, peer debriefer, and two other researchers in the department.

\section{Trustworthiness}

There are multiple ways that have been discovered to promote trustworthiness and validity within qualitative research. For this study, trustworthiness was insured through four techniques, which included triangulation, the use of a peer debriefer, use of multiple researchers $\&$ an audit trail.

Triangulation, was used as a primary strategy to emphasize and increase the internal validity of this research. Patton (2015) explains "triangulation, in whatever form increases credibility and quality by countering the concern that a study's findings are simply an artifact of a single method, a single source, or a single investigator's blinders" (p. 674). Triangulation was generated through the use of multiple sources for data collection. The researcher was able to compare and cross-check data multiple times throughout the data collection with the different sources.

Another approach used to fulfill trustworthiness was peer debriefing. An experienced and knowledgeable researcher assisted in this process. Merriam and Tisdell (2016) mention the purpose of this strategy is to determine whether findings from the data are plausible. Multiple researchers on the research team were used in the process of analysis. This strategy ensured credibility of the interpretations of the participants' expressions.

Finally, a log in a research journal was kept regarding what was done throughout the entire research process. This is a method suggested by Lincoln and Guba (1985) called audit trail. An audit trail is simply a detailed account about the methods, data collection, analysis, and 
decisions made throughout the inquiry. The audit log kept a running record of the research process as it was being conducted. The quality of the study can be assured with the use of an audit trail. It is suggested that if the reader can review the events and actions of the researcher during the process then trustworthiness may be established (Koch, 2006).

\section{Findings}

The purpose of the study was to investigate the influence of engaging in service learning in an after-school program and mentoring at-risk youth on the socialization process of PSTs. Specific research questions included: (a) how do PSTs describe their experiences as a student in K-12 PE? (b) how do PSTs describe their experiences while going through the PETE program? (c) how do PSTs describe their experiences in the ASP and how it is shaping their beliefs? (d) how do PSTs describe their experience mentoring an at-risk child?

Data revealed three themes from the participants' experiences: (1) Additional practical experiences developed comfort and confidence, (2) Relationships and in-depth knowledge of children, (3) Internalization of the obligation to model healthy social-emotional behaviors.

\section{Additional Practical Experiences Developed Comfort and Confidence}

Over the course of the ASP, each PST delivered multiple physical activity and nutrition curriculum lessons to the group. The PSTs overwhelmingly described feeling that this added practice helped them feel more comfortable and confident in the role of teacher. They perceived this impacting their performance concurrently in their teaching in the formal K-5 practicum course in the PETE program. Mary's thoughts expressed this best saying:

It helped me be more comfortable teaching students because I was focusing on teacher position, my voice, classroom management. [Working in the ASP] helped 
me a lot in my practicum last semester because I was overwhelmed but I became more comfortable doing it because of the ASP. (Mary, Interview \#3)

The PSTs spoke specifically about how teaching opportunities within the ASP allowed them to spend additional time improving their basic pedagogical skills like teacher positioning and other classroom management techniques. For example, Mary wrote:

I found that to help with my nerves when teaching and now this semester, I can focus more on the little things rather than the classroom management or the bigger ideas. (Critical Incident \#2)

More specifically, the PSTs expressed how the alternative and lower-stakes context of the ASP allowed them to relax which led them to feel more comfortable and confident. About this, David said: "I think the [ASP] experience helped me sit back and relax a little bit more" (David, Interview \#3).

Aside mentoring in the ASP, the additional teaching practice within a different instructional context caused the PSTs to gain confidence and comfort in occupying the role of teacher. The students specifically described how these extra lessons allowed them to feel more relaxed and they believed helped further their teacher development. They described feeling as though this directly impacted their performance in the PETE program.

\section{Relationships and In-depth Knowledge of Children}

The PSTs developed personal and in-depth relationships with the children in the ASP. Through these relationships, the PSTs learned about the children's personal lives, home environment, and history. As a result of this knowledge, the PSTs in this study became very aware of what the children experienced at home and described seeing this impact the children's performance and behavior at the ASP. They described this saying: "You just don't know what's 
going on in their lives" (Cody, Interview \#3) and "You need to be more understanding of other things going on" (David, Interview \#3). More about this, David said:

I think [working in the ASP] really helped me understand the role that school plays in their lives. I think knowing their history has helped me understand why they might act that way in class... because there is just so much you can learn from getting to know the student's perspective. (David, Interview \#4)

The PSTs expressed that the knowledge they gained about students caused them to have a strong recognition of the importance of knowing students in order to teach more effectively. A few of the PSTs had described times where they had to handle difficult situations due to behavior. Sometimes, a mentee would not want to participate in the activity or other times, something triggered and made the child very angry during a game. By building these in-depth and deep connections with their mentee, it allowed the children to feel more comfortable expressing how they were feeling or what they were going through to the PSTs. At the end of this mentoring experience, the PSTs were able to take away the importance of knowing your students and figuring out how to be more personable with each to better understand their behaviors and reasons in class. It was expressed that now the PSTs have the necessary tools to handle situations when a child is not wanting to participate or had to sit out of the activity. These situations can be handled in a more positive and caring manner to get the student(s) back into the lesson. Marianna explained:

My mentee would always get upset and sit out. I tried to talk to him, but I wouldn't get a whole lot of answers. Finally, one day he talked to me about why he was upset and sitting out...it showed me that not all children are the same and they all have their own insecurities. It made a significant impact on me as a 
teacher because it showed me that if you let the students know you care about them, they will open up more and they will be more engaged. If they decide to sit out, now I know how to handle the situation so that I can get them back into activity as soon as possible. (Marianna, Critical Incident \#3)

Deeper knowledge of the children caused them to have a heightened awareness of the significant need for serving at-risk children. The PSTs in this study described feeling a sense of duty or calling in supporting, guiding, and reaching underserved children. In response to the question: "What would you tell another pre-service teacher about working in the ASP?" Cody said, "I think it's important that they understand these are the kids that they need to be working with" (Interview \#4). Similarly, Marianna talked about an increased awareness of at-risk populations with a recognition that "[at-risk youth] are the ones that need [help and guidance] the most" (Marianna, Interview \#4).

\section{Internalization of the Obligation to Model Healthy Social-Emotional Behaviors}

While working as a mentor, the PSTs developed an understanding of the at-risk children's social-emotional behaviors and skills they possess. Within this mentoring role in the ASP, the PSTs took recognition that the "children are watching you." They began to notice that this population of children may not witness these healthy behaviors being demonstrated by those closest to them in their daily lives at home. Based on building those relationships and developing profound knowledge of the children, the PSTs expressed it was their duty to be the one who modeled healthy social-emotional behaviors during the ASP. Larry expressed his internal obligation to model these behaviors as he mentioned:

I feel like when I'm teaching and mentoring, I think "Oh, I'd better do the right thing"...these kids are watching me...I feel like as a teacher and a mentor you 
have to be doing the correct things because they are looking up to you for that, if they're not seeing you do the right things they won't think they need to do the right things. (Larry, Interview \#4)

The PSTs felt a personal obligation to model healthy behaviors, specifically healthy social/emotional behaviors as a result of the recognition that this population may not have the opportunity to see these types of behaviors modeled for them in the home environment. Awareness of the power of their position as teacher in the lives of at-risk youth, in particular. For example, Beth wrote: "My mentee had a pretty tough home life and being a positive person in his life is really important" (Critical Incident \#4).

Further, the PSTs in this study described that work in the ASP caused them to have an increased awareness of attending to the affective domain of learning in order to provide at-risk youth with the opportunity to develop the personal-social skills necessary to get along with others both inside and outside of school. The PSTs realized the importance to teach and incorporate social and responsible skills within the PE context. About this, David stated: I realized that I could help change that kind of behavior through my teaching...I feel like I will be preparing them for the real world, where they will need to collaborate and respect others. (David, Critical Incident \#4)

As a teacher in the future, the PSTs learned that they should be that role model who teaches the students how to act appropriately in society. Again, Marianna expressed her thoughts on being that teacher who teaches necessary social-emotional behaviors that they may not learned outside of school. She said, "I need to teach them how to be a good partner, how to treat others because if they're not taught that at home I feel like that's my role" (Marianna, Interview \#4). As a result of mentoring at-risk children, the PSTs learned that students may or may not 
learn appropriate and healthy social/emotional behaviors outside of school. Because of this, they felt a strong responsibility as a teacher to model and develop these skills in students.

\section{Discussion}

The purpose of the study was to investigate the influence of engaging in service learning in an after-school program and mentoring at-risk youth on the socialization process of PSTs. The PST's acculturation experiences were powerful determinants in their reasons for entering the profession of PE. The experiences and knowledge gained by the PSTs in this study served to construct a view of teaching that includes a strong emphasis on knowledge of students and focus on affective skill development. Our findings are consistent with existing literature and extend the knowledge base regarding acculturation experiences, the importance of practical experiences, and on the position of after-school programs in supporting and furthering PETE programs.

\section{Acculturation}

Concerning the first research question, the results provided insight of how previous K-12 experiences in school as a student impacted and influenced these PSTs which led them to this profession. The acculturation phase of teacher socialization can have the greatest impact on individuals deciding to enter this profession (Curtner-Smith, 1999; Richards et al., 2014). Former experiences and interactions as a student in the PE context influences individual's beliefs and values about the subject and teaching (Schempp \& Graber, 1992). Our findings are consistent with this literature. The PSTs in this study were strongly influenced by acculturation experiences as K-12 students in PE. Their personal experiences were communicated as some being positive, but mostly negative in K-12 PE. This is consistent with existing literature as Templin and Richards (2014) mention individuals attitudes towards PE can be influenced by previous experiences and could be a primary reason why they enter this profession. These PSTs likely had 
a strong subjective warrant related to $\mathrm{PE}$ and therefore chose to pursue the preparation program to become a physical educator (Russell, Gaudreault, \& Richards, 2016). There are many other reasons and factors of why individuals choose to teach as a career. Often, previous teachers and coaches can have an influence on this decision (Templin \& Richards, 2014). This was similar to the PSTs in this current study. It was described how previous PE teachers and coaches played a significant role in shaping their ideas about physical education as a subject and the PSTs reasons for entering the profession. These teachers and coaches were often seen as a role model in the eyes of the PSTs and possessed special characteristics.

PSTs in this study described some negative experiences in PE and entered the profession with a disposition to change that experience for other children. Frequently, recruits who choose this profession are ones who had positive interactions and experiences with their PE teachers and coaches. Although, Stran and Curtner-Smith (2009) find that it can be motivating if an individual had negative experiences during K-12 PE and sports to become a physical educator. This was the case for a number of these participants in this study. They felt rather than emulating their experiences and behaviors from PE class they had, the PSTs wanted to teach to help future students not have similar experiences as them.

Each of the PSTs in this study had a teaching orientation. It has been supported by recent literature that recruits are entering the profession more focused on teaching rather than other aspects such as coaching (O’Bryant, O’Sullivan, \& Raudensky, 2000). This has been a paradigm shift over the last decade. Studies conducted by Curtner-Smith, Hastie, and Kinchin (2008); Richards and Templin (2011), and Stran and Curtner-Smith (2009) have supported this finding of recruits possessing a teaching orientation and wanting to help children. 


\section{Professional Socialization}

\section{Impact of practical experience in the ASP.}

Additional practical experiences delivering lessons supported the PSTs in feeling more comfortable and confident in the role of teacher. The opportunity to practice basic pedagogies like teacher position, positive pinpointing and checks for understanding within the context of the ASP helped these teaching behaviors to develop more quickly and allowed the PSTs to attend to other more advanced elements within their practicum/methods courses. Throughout practical field experiences, the PSTs concerns progress through developmental phases (Behets, 1990). More specifically, the added teaching experiences in the ASP allowed the PSTs to focus on students and their learning earlier in their practicum experiences. This finding leads us to believe that additional practical teaching experience within the context of after-school programs may further expedite the progress of PETE students through the developmental phases proposed by Behets. More specifically, it may be that PETE students who have these additional teaching opportunities may more quickly arrive to a place where they are able to move beyond focusing on their own teaching behavior and begin to demonstrate the ability to focus on or attend to students and context. Further research is needed to determine how these types of extra practical experiences impact PSTs progression through these developmental phases.

\section{Impact of mentoring.}

Findings from this study express ways the PSTs were impacted by the mentoring experience. The close personal relationships that the PSTs formed with the at-risk youth in the ASP significantly impacted their knowledge of students. As a result, they internalized a strong belief in the importance of knowing students for when they become a teacher in the profession. This finding was comparable to Szente (2008) who found that PSTs knowledge and 
understanding about students and pedagogies increased after engaging in a service learning experience.

For the PSTs in this study, knowledge of students went beyond knowing children's skill level and performance in the psychomotor or cognitive domain. As a result of mentoring, the PSTs in this study were able to gain an in-depth understanding of the personal, social, familial, and contextual factors that impacted the children's lives each day. Our findings indicate that participating in a service learning project with a different population of students can have a positive impact on PSTs development and dispositions toward teaching and students. Domange and Carson (2008) found PSTs began to understand the importance of having these types of experiences with different a demographically diverse population of students. Similarly, Bell, Horn, and Roxas (2007) found mentoring during service learning experiences facilitate and grow PSTs' understanding of diversity due to doing activities and connecting teaching and learning experiences. Having experiences with different demographic populations can increase those individual's cultural understanding and social responsibility (Domangue \& Carson, 2008; Kaye, 2010). These experiences allowed the PSTs to learn more about their child's diversity and individual needs. Further, the PSTs were able to witness firsthand how these factors affected the children's behavior in the regular classroom, on the playground at recess, and within the ASP. Because of this, the PSTs in this study recognized that knowledge of students and knowledge of context as significant sources of knowledge for teachers in order to reach all students.

Mentoring experiences can positively impact both individuals part of the relationship. Mentoring at-risk children can work toward impacting the disposition of PSTs toward children who research indicates tend to receive less attention. Specifically, our findings seem to indicate that mentoring experiences with at-risk youth can result in PSTs having an increased awareness 
and value for focusing on low skilled students, unfit students, and others who are not highly skilled. Further, our findings indicate that opportunities to develop relationships with at-risk children and work with them within an ASP may also result in improved teaching of affective goals and objectives.

PSTs in this study frequently described themselves as feeling more comfortable in teaching and mentoring due to taking on the mentor role. The sense of feeling satisfied, comfortable, and confident is consistent with other scholars' work in this area (Beltman \& Schaeben, 2012; O'Shea et. al, 2013). Mentors from other studies conducted expressed a sense of achievement and satisfaction while helping their mentee (Beltman \& Schaeben, 2012; Ghosh \& Reio Jr., 2013). These PSTs not only grew as a future educator but also personally. Collier called for a "design and delivery of teacher education that allows for the development of caring teachers who take time to develop the emotional dimensions of their pedagogy" (p. 367). Our findings seem to indicate that experiences mentoring and working with at-risk youth within ASPs may provide PETE faculty with one way to do this.

\section{Implications for PETE Programs}

Additional practical experiences can enhance teacher knowledge development and support PETE programming. PETE faculty should look to create opportunities for PSTs to engage with children in authentic settings. ASPs provide an opportunity for PSTs to gain valuable confidence and comfort in the role of teacher and these experiences can assist PSTs pedagogical development as they may expedite the learning of some basic and fundamental pedagogical behaviors. These experiences should be in addition to more formal practical experiences within PETE programming. 
One suggestion would be to create opportunities for PSTs to teach in contexts outside of a traditional K-12 PE class. Although, having practical teaching experience in the PE context is crucial and much needed, practicing in other contexts would allow even more opportunities to grow and develop as a beginning teacher. These opportunities could consist of before or after school programs. It would be beneficial for PETE programs to engage with schools and community resources for programs for the PSTs to experience. Teaching in different contexts would enhance the development of basic pedagogy skills. Therefore, that would result in increased comfort and confidence in the role of the teacher. Often, PSTs are nervous and overwhelmed with being supervised during their practical teaching experiences in the PE classroom. Allowing these different opportunities could allow the PSTs an environment where they feel more relaxed and they can practice their pedagogies with less stress of being graded and critiqued.

Another suggestion for PETE programs is to look for opportunities for PSTs to mentor or be in one to one situations with children. Providing PSTs such opportunities can enhance their knowledge of children. During the two years of a PETE program, often PSTs are so focused on primary pedagogy skills and knowledge of the content that knowledge of students lacks (Behets, 1990). The ability to focus on students and their learning is advanced for PSTs. It has been noted this is the final area of teaching that PSTs attend to. Mentoring experiences can allow PSTs to develop knowledge of students earlier in the program. Also, opportunities like these in a PETE program would increase PSTs appreciation for contextual factors that affect student behavior and performance. Other areas of knowledge and skills would begin developing sooner in their preparation program which will impact them in the induction phase of teaching. 
Findings from this study confirm the importance of practical experiences while going through a teacher education program. Future studies should continue exploring the impact of mentoring on mentors and how this impacts the socialization of teachers into the profession. 


\section{CHAPTER II: EXTENDED LITERATURE REVIEW}

This literature review will highlight and summarize the foundation framework and aspects for this study. Relevant literature upon the theory and topics will be critically reviewed. The following sections will discuss these issues through the presentation of the topics of: (a) Occupational Socialization Theory, (b) teacher socialization, (c) PETE programs, (d) service learning experiences, (e) after-school programs, and (f) mentoring.

\section{Occupational Socialization Theory}

Occupational Socialization is conceptualized as the different socializing processes that influence an individual to become a physical educator and their viewpoints and behaviors throughout the career (Lawson, 1986). Occupational Socialization Theory (OST) is a theory of teacher socialization in PE that investigates the aspects of becoming a physical educator and in the profession. Teacher socialization is divided into three sequential phases that define the process of teacher socialization in PE. The three stages of OST include acculturation, professional socialization, and organizational socialization (Lawson, 1983; Lortie, 1975). The following sections will go deeper into the understanding of each phase.

\section{Acculturation}

Acculturation is the first phase of teacher socialization. This is the process that occurs well before an individual chooses the path of being a PE teacher. The acculturation phase begins nearly at birth and continues until an individual gets into a PETE program. This phase explains how individuals are socialized in PE through personal experiences and interactions (Lawson, 1983). At this point in the process, one's thoughts and perceptions of teachers and coaches are formed through interactions with them. Past experiences can potentially influence an individual's behavior and attitude towards teaching PE and perhaps on why an individual wants to become a 
PE teacher or coach (Templin \& Richards, 2014). Based on the three phases of teacher socialization, scholars have noted that the acculturation phase has a more powerful influence on an individual rather than PETE program or career experiences (Curtner-Smith, 1999; Richards et al., 2014). Reasons for this might be because an individual is exposed to those personal experiences for twenty plus years of their lives, plus at such an impactful developmental age. The acculturation phase is influenced by factors of apprenticeship of observation and subjective warrant.

\section{Apprenticeship of observation.}

All the personal experiences one is exposed to within their PE classes during K-12 schooling are known as apprenticeship of observation (Lortie, 1975). These experiences may also be sports participation in athletic settings. It has been supported by multiple studies that these past experiences play a major role in the acculturation process (Curtner-Smith, 1996; Flory \& McCaughtry, 2014; Templin \& Richards, 2014). Students or athletes are frequently referred to as recruits of the future PE profession (Richards, Templin \& Graber, 2014). PE is a profession that individuals have vast experiences with while growing up compared to other occupations such as lawyers, nurses, or secretaries.

Schempp and Graber (1992) mention there is a direct impact from previous experiences on individual's beliefs and values about PE and teaching. The interactions one has had with coaches and PE teachers and the experiences along with those contexts have been described as a positive reason and influence on their career path (Templin \& Richards, 2014). Recruits are ingrained with information and beliefs about PE based on their positive or negative experiences at the young age. Often recruits are ones who had positive interactions with their PE teachers and coaches, however, sometimes recruits want to become physical educators because they want 
future generations to have better and different experiences than they had. The apprenticeship of observation can have a lasting impact on how a recruit interacts in a PETE program and what kind of PE teacher they become.

\section{Subjective warrant.}

During the process of apprenticeship of observation is when individuals develop the notion introduced by Lortie (1975) of subjective warrant. Lawson (1983) describes subjective warrant as the perceptions an individual has about the necessities it takes to be a physical educator in schools. Based on those personal experiences and observations a recruit has made, perceptions are formed about what it takes to fulfill a position in this profession. Depending on a recruit's skill or athletic abilities and the quality of their PE program during apprenticeship can impact if they have a high or low subjective warrant for PE. Regardless their subjective warrant, the recruits are able to determine whether or not they would be capable of meeting the challenges to become a PE teacher. (Lawson, 1983). With the countless hours that are spent in the school and sport setting and contact with the content provides opportunities for both apprenticeship of observation and subjective warrant to be shaped.

\section{Professional Socialization}

Professional socialization phase begins when the recruit transitions out of K-12 school and into a college/university setting for teacher training (Stroot \& Ko, 2006). The purpose of this stage is to get PSTs prepared to effectively teach PE in the school setting. During this stage, teachers and coaches become more familiarized with the skills, effective practices, and morals of teaching (Lawson, 1983). The PSTs also begin developing beliefs and values related to the profession during their PETE programs. The apprenticeship of observation plays a major role in this phase of teacher socialization. It can be challenging for PETE programs to instill the best 
practices and beliefs of PE and teaching because of their conceptualized subjective filters. Often, if practices do not match with PSTs perceptual beliefs, they will begin to resist change. Graber (1991) identified this pushback behavior as studentship. These clashes may reside from apprenticeship observations of traditional PE as a student where the PETE program may be incorporating new effective practices in PE. Although some teacher education programs teach

through theory, it is suggested this needs to be renovated. Best practices in PETE programs come from providing field-based teaching which allows PSTs to experience hands-on teaching children in the real context. It has been noted by researchers that these programs must prepare students for the realities of teaching (Richards et al., 2013). This could help limit the number of teachers who experience reality shock as an induction teacher and fall into the washout effect. Those three researchers also recommend teacher education programs should incorporate instruction and discussion about the reality in school environments and solutions for these types of contextual issues (Richards et al., 2013). PETE programs are supposed to prepare PSTs to be successful and effective physical educators and this must include organizational context challenges.

\section{Organizational Socialization}

The final phase of teacher socialization is organizational socialization. This begins when a recruit enters teaching and continues through until career exit. However, the first three years in the profession is the most significant (Stroot \& Ko, 2006). Lawson (1986) described this phase as "all of the kinds of socialization that initially influence personas to enter the field of physical education and that later are responsible for their perceptions and actions as teacher educators and teachers" (p. 107). Organizational socialization allows the teacher the opportunity to use the skills and behaviors that were taken from their PETE program, as well as begin developing their 
own PE program in a school setting. The professional's beliefs, values, and experiences continue to change and grow throughout their career.

\section{Workplace factors.}

Workplace factors can hinder or benefit the well-being of a teacher during their career. These factors will influence an individual at different points in their career, not just specifically during the induction phase. Although, induction teachers may feel more of a negative impact of certain workplace factors due to all the stress and being in the new environment. Lawson (1989) discussed factors within the workplace to be associated with politics, organization, situations, and personal-social.

\section{Induction.}

The first three years of a teacher's career is identified as the induction phase. The professional is able to test the knowledge and practices learned during the PETE program within the reality setting. This phase provides additional unique challenges as new teachers are unfamiliar with cultural norms of schools and other varying socializing agents which they encounter (Curtner-Smith, 2001). PETE programs are limited to exposing PSTs to socializing challenges in the real teaching context, therefore this can be a difficult and stressful adjustment for new teachers. Research has indicated that new teachers in the profession will often describe to conform to the school's current teaching practice to avoid issues with colleagues even if they do not align with their own beliefs and practices (Richards \& Templin, 2014). There is a direct link between their experiences during the first two stages of teacher socialization and how teachers react during the induction phase.

In a study conducted 1998, findings were found that induction teachers were often compliant with their peer teachers to make their life in school easier. Common struggles were 
associated with marginality, isolation, and management (William \& Williamson, 1998). These findings were similar to previous literature about induction teachers (O’Sullivan, 1989; Stroot, Faucette, \& Schwager, 1993).

\section{Washout effect.}

Induction teachers may face reality shock as a result of the socializing issues and challenges in the school setting. Veenman (1984) defined reality shock as, “...the collapse of the missionary ideals formed during teacher training by the harsh and rude reality of everyday classroom life" (pg. 143). If the beginning teachers choose to comply with the current school practices, over time, they may experience the washout effect. Several factors in the workplace can contribute or inhibit the washout effect. Findings from research suggest washout includes a decrease in lesson planning preparation, confidence to overcome limitations, and fewer interactions with instruction (Blankenship \& Coleman, 2009). This effect occurs when the teachers stop implementing the teaching behaviors and strategies that was learned from their PETE programs due to the pressure to imitate their colleague teachers. In this respect, the behaviors taught throughout the PETE program wash out and are excluded from their current practices.

\section{Teaching and coaching orientations.}

Every teacher enters the profession with some type of orientation. Lawson (1983) discusses orientations teachers may have are full coaching orientation, straight teaching orientation or an equal of both. This simply means their primary focus relates to strictly teaching or coaching. Frequently, recruits choose to become a physical educator for coaching. Lawson (1983), observed that most recruits entered teaching with a coaching orientation. These recruits were also made aware that they were hired to focus on coaching a sport. However, within the $21^{\text {st }}$ 
century, there has been a paradigm shift of recruits and their orientations they bring entering the program (Pike \& Fletcher, 2014). Teaching orientations are predominately seen in newer recruits entering preparation programs (Richards \& Templin, 2011; Stran \& Curtner-Smith, 2009). It was mentioned by Richards and Templin (2011) that recruits who have a strong teaching orientation are more willing to change their perceptions related to the profession in the PETE program. Whereas, strong coaching orientation individuals are not as receptive to the content (Templin \& Richards, 2014). Once beginning teachers are in this real-life setting, dilemmas can occur to which role required their time and effort.

The apprenticeship of observation and subjective warrant influences these orientations during the professional socialization phase. Depending on what types of interactions recruits have during their experiences, will impact and determine which orientation one will enter the PETE program with. Recruits may observe during the acculturation phase that many PE teachers also coach some sport. Throughout the teacher education phase, PSTs orientations can be subjective to change. Although the program may not have a great influence on changing, the views and beliefs taught in the PETE program could persuade what orientation they should have. Along with that notion, induction teachers may find their orientations changing during the organizational phase due to facing teaching realities in the school culture.

\section{PETE Programs}

The way teacher education programs prepare teachers is directly influenced by the National Council for Accreditation of Teacher Education (NCATE). More specifically, standards and accreditation for PETE programs are followed by the National Association of Sport and Physical Education (NASPE). These standards are focused on knowledge and skills needed to 
plan, implement, and evaluate PE programs. Over the last few years, incorporating fitness into PETE program standards has been up for debate.

PSTs are practicing individuals who are in the learning process of being an educator. Physical educators must go through a professional preparation programs to prepare and become licensed PE teachers. Research examining educational programs for PE often use FeimanNemser (1990) work for theoretical orientations. Those orientations include practical, academic, personal, technological, and critical. This framework is similar to others work in teacher education such as Doyle (1990) and Zeichner (1983). Teachers have a direct impact on how students choose to be physically active, and their value for PA based on what the teacher says and does.

\section{Service Learning Experiences}

The idea of service learning has a variety of different meanings with scholars (Wang \& Jackson, 2005). Minor (2002) refers to service learning as a "union of community service and formal learning" in a diversity of settings (p. 10). Service learning is often linked with active learning and is a way students can help others while applying knowledge (Weis, 2004). The purpose of this teaching strategy is to provide individuals with civic engagement opportunities. Service learning can be incorporated at any level of education setting (Baldwin, Buchanan, \& Rudisill, 2007; Bollin, 2007). Universities, particularly, in the United States have noted by integrating service learning into the teacher education programs can promote high-quality academic learning for students. Research in this area is often examined in PETE programs with PSTs (Cervantes \& Meaney, 2013; Domangue \& Carson, 2008; Peralta, O’Connor, Cotton, Bennie, 2016; Wilkinson, Harvey, Bloom, Joober, \& Grizenko, 2013). 
Research studies continue to support the strong evidence that using Service Learning in preparation programs provides positive outcomes for students and community. Scholars, GilGomez, Chiva-Bartoll, and Marti-Puig (2015), answered four research questions, but one primary finding was the PSTs acquired more adequate teaching skills. The skills were used in the real context of PE and connected with the idea of connecting theory and practice. The number of studies related to cultural diversity and awareness with service learning has increased (Domangue \& Carson, 2008; Kaye, 2010; Rogers, Marshall, \& Tyson, 2006). These experiences fulfill students to build more of a cultural understanding and social responsibility. Researcher Szente (2008), conducted a study and the results found the students had more growth in the understanding of students and pedagogies. In this aspect, it supports the findings above as the PSTs were able to learn more about the individual student's diversity and needs. Furthermore, there is found to be a connection between helping others during service learning experiences can develop and enhance student's communication skills and confidence (Katz, DuBois, \& Wigderson, 2014). All of these findings indicate that service learning increases deeper cultural sensitivity, academic knowledge, and personal/social skills.

\section{After-school Programs}

Over the last decade, participation and funding for ASPs have consistently grown. Youth age students spend more waking hours of the day at school than at home. After school hours, students are associated with either organized or unconstructive activities. According to recent data, across the United States, approximately 6.6 million children participate in some type of program after school (Afterschool Alliance, 2004). If ASPs were available, millions of more families show interest. Youth who do not take part in some type of ASP often make risky choices and unhealthy behaviors (Mahoney et al., 2005). Whereas students participating in ASPs can 
limit the problem behaviors with increased educational achievement and many other positive outcomes (Mahoney et al., 2005). ASPs are structured programs that are organized after school hours and supervised with activities for students. These are options youth can go to that have a direct connection to school. Scholars have now been examining the benefits ASPs can provide for students involved.

ASPs are emerging as an approach to deliver experiences to promote and develop positive youth behaviors and outcomes (Tebes et al., 2007). While examining the benefits associated with positive youth development, the positives outweigh the negatives with student participation and engagement. Literature not only have found benefits to be correlated with academic and social skills (Durlak et al., 2010; Kahne, Nagaoka, Brown, O’Brien, Quinn, \& Thiede, 2001; Roth, Malone, Brooks-Gunn, 2010), but also more PA (Beighle et al., 2006; Trost, Rosenkranz, \& Dzewaltowski, 2008). Although ASPs engage all students, a large portion of participants come from families who have low to moderate income base. The programs can provide a safe environment to go to after school and low-cost effective activities.

A variety of ASPs have emphasized the impact on academic learning. Academic outcomes consist of better attitudes towards school, increased attendance, better performance in school on tests and more engagements in their learning. In the early 1990s, researchers Posner and Vandell (1994) found that low-income students who participated in the formal ASP received better grades and behavior in school. A two-year longitudinal study was conducted to examine outcomes that were linked with high-quality ASPs. The results were consistent with both elementary and middle school-aged participants. Over the two years, the students showed significant gains on their standardized math test scores. The younger participants made gains with social skills with peers and aggressive behaviors. Less usage of drugs and unhealthy 
behaviors were reduced with the middle school students who regularly participants at the programs (Vandell, Reisner, \& Pierce, 2007). Finally, 35 quasi-experimental studies of ASPs for at-risk youth were combined for a meta-analysis by Little and colleagues. These program's results demonstrated significant positive effects on student achievement in both reading and math. Collectively, these show participants' outcomes of ASPs have been found to be related to academic achievement.

In today's world, the obesity rate of youth is higher than ever in the United States. With PA opportunities diminishing throughout the school day for children, ASPs can provide youth the opportunity to increase the amount of their PA. Tutoring and homework clubs are known as most common types of ASPs, but PA engagement is becoming more popular. Beets, Beighle, Erwin, \& Huberty, (2009), "identified that after-school programs focusing on physical activity to be a recent trend" (p. 1). There is evidence to support that providing a physical active focused program provides the potential to elicit children to receive the recommended 60 minutes of daily moderate-to-vigorous PA recommendations (U.S. Department of Human Health Services (USDHHS), 2016). ASPs can continue to contribute to the positive development of youth as research findings support benefits for youth PA.

All in all, these ASPs show a positive influence on the youth development of students. Based on this evidence, the results and outcomes for students still vary depending on the quality and frequency of the ASPs. Each program will have their own focus, but the overall outcome for ASPs is to build positive youth development by focusing on the social and cognitive domains such as problem solving and social relationships, which are seen as important concepts of positive youth development (Smith, 2004). 


\section{Mentoring}

The seminal work of Kram (1985) provided a framework for mentoring as socializing agents as a facilitator within the socialization process. The construct of mentoring has been examined for the past four decades. The fields of education, management, and psychology have unlocked lines of inquiry regarding aspects of mentoring (Jacobi, 1991). Multiple interpretations, meanings, and definitions related to "mentoring". It has been noted that there is a vast number of different working definitions used by scholars (Haggard, Dougherty, Turban, \& Wilbanks, 2011). Kram (1985) describes mentoring as a developmental relationship including peers or members of unequal status. Mentoring is conceptualized as a mutually benefiting relationship for both the mentor and mentee. In general, a mentor is "any caring, mature person who forms a oneon-one relationship with someone in need" (Dondero, 1997, p. 882). Kram (1985) explains a mentor who assists and provides various psychosocial and career support for the mentee. A person in the mentor role may also offer guidance and counseling to one. A person in an organization who is less experienced in that role would be considered a mentee (Kram, 1985). Four stages of a mentoring relationship have been identified by Kram (1985). These four stages include: initiation, cultivation, separation, redefinition. The stages are an upward spiral where both people part of the relationship may flourish. The mentoring relationship can fluctuate between these four stages. Accordingly, significant research about mentoring focuses solely on benefits and outcomes associated with the mentees and less understanding of how it affects the mentors (Allen, 2007; Beltman \& Schaeben, 2012; Bozionelos, 2003; Chun, Sosik, \& Yun, 2012; Ghosh \& Reio Jr., 2013).

Based on the cultural context, scholars have investigated a variety of forms of mentoring. Thus, mentoring has been examined in the context of work-area focused on career development 
(Boudreau, Boswell, \& Judge, 2001; Bozionelos, 2003; Chun, Sosik, Yun, 2012; Fagenson, 1989; Kram \& Isabella, 1985; Raggins \& Cotton; 1999; Raggins \& Scandura, 1999), as few concentrate in the education and universities context of mentoring (Allen, 2007; Beltman \& Schaeben, 2012; Jacobi, 1991; O’Shea et, al., 2013). In organizations, mentoring can be used as a development tool. Notably, authors Kram and Isabella (1985) demonstrate how mentoring relationships, the development of individual's career stages has an ability to enhance the socialization process. Utilizing relationships through mentorship in organizations have shown to provide career benefits to the mentors. No matter the success of the mentoring relationship, there will always be outcomes; whether those are positive or negative. A significant amount of literature suggests that a positive outcome of feeling satisfied will derive from a mentor who may be less experienced within an organization (Ghosh \& Reio Jr., 2013; Hunt \& Michael, 1983). When mentorship experiences, individuals tend to receive enriched opportunities related to career decision; therefore, findings related to job performance and career success are improved (Ghosh \& Reio Jr., 2013). A final benefit of being part of a mentoring relationship is future mentorship. Limited studies concerning career success show that individuals who have been mentored by someone before will likely become a mentor themselves in the future. If already in the role of mentoring, the mentor is more likely to continue mentorship of individuals (Bozionelos, 2003; Raggins \& Scandura, 1999).

Two specific researcher studies found regarding mentor benefits within education. Beltman and Schaeben (2012), conducted a study looking at how peer mentoring benefited mentors for high education students at a university. Findings from this qualitative study presented four emerging themes: altruistic, cognitive, social, and personal growth. The peer mentors felt the sense of achievement and satisfaction for helping their mentee, in which was a 
similar feeling of individuals in their careers. Typically, mentors took pride in their role and gained confidence within. In a similar study with Indigenous Australian college-aged mentoring students, a significant finding from numerous mentors was their feeling of growth within selfawareness and confidence (O'Shea et, al., 2013).

When examining mentoring, relationships are divided into two different forms; informal and formal (Chun et al., 2012; Raggins \& Cotton; 1999). An informal mentor relationship is when the mentor and mentee mutually choose each other based on perceived competence and comfort. Whereas a formal mentoring relationship is when a mentor and mentee are assigned together by a boss or coordinator of the organization. A longitudinal study conducted by Chun et al., (2012), examined transformational leadership as a mentor outcome in a formal mentoring relationship. Findings supported previous evidence of role modeling and career support functions were significantly related to mentors' transformational leadership.

Each of these studies supports numerous benefits for the mentor from these types of relationships within a different context. Generally, scholars have identified limited research on the potential benefiting factors for mentors from mentoring as one of the critical gaps in the literature (Chun et al., 2012). This study will provide support in two needing areas. In regards to mentoring, research will be gained on seeing how this program and mentorship impacted the mentors of the children.

\section{Conclusion}

Socialization occurs throughout the entire career of an individual. OST underlines three different socialization processes that all teachers encounter during their careers. The three stages of socialization are acculturation, professional socialization, and organizational socialization. Acculturation reflects the initial personal experiences an individual has throughout their K-12 
education. Based on those previous experiences will influence a recruit if they choose to become a physical educator. If so, they become part of the professional socialization process once they take their education further in a PETE program. Finally, the organizational socialization stage marks the time period when teachers are inducted into the teaching process. All throughout these different phases, beliefs, perceptions, and values change for a professional regarding their profession. This model can continue to help understand the impacts of being socialized in the profession.

ASPs and mentorship have become more of a valuable asset to positively enhance youth development. Given opportunities during the professional socialization phase can influence the socialization process of a teacher. Research shows collectively that the mentoring relationship will impact the mentor and mentee positively. Mentoring can be part of a service learning experience within a PETE program to help professionally, but also with the socializing process. Findings from this study may provide PETE programs insights into how an ASP, more specifically one on one mentoring can influence teacher socialization. It might also PSTs an idea of how socializing can impact them as teachers in early stages of their career. 


\section{REFERENCES}

Afterschool Alliance (2004). America after 3pm: A household survey on afterschool in America. Available at http://www.afterschoolalliance.org/press_archives/america_3pm/Executive_Summary.pd f

Allen, T. D. (2007). Mentoring relationships from the perspective of the mentor. In B. R. Ragins \& K. E. Kram (Eds.), The handbook of mentoring at work: Theory, research, and practice: $123-147$.

Baldwin, S. C., Buchanan, A. M., \& Rudisill, M. E. (2007). What teacher candidates learned about diversity, social justice, and themselves from service-learning experiences. Journal of Teacher Education, 58(4), 315-327.

Baugh, S. G., \& Sullivan, S. (2005). Mentoring and career development. Career Development International, 10(6/7), 425-428.

Beets, M. W., Beighle, A., Erwin, H. E., \& Huberty, J. L. (2009). After-school program impact on physical activity and fitness: a meta-analysis. American Journal of Preventive Medicine, 36(6), 527-537.

Behets, D. (1990). Concerns of preservice physical education teachers. Journal of Teaching in Physical Education, 10, 66-75.

Behets, D. and Vergauwen, L. (2006). Learning to teach in the field, in: D. Kirk, D. Macdonald and M. O‘Sullivan (Eds.) The handbook of physical education (London, Sage), 407-424.

Beighle, A., Morgan, C. F., Masurier, G. L., \& Pangrazi, R. P. (2006, December). Children's physical activity during recess and outside of school. Journal of School Health, 76(10), 516-520. 
Bell, C. A., Horn, B. R., \& Roxas, K. C. (2007). We know it's service, but what are they learning? Preservice teachers' understandings of diversity. Equity \& Excellence in Education, 40(1), 123-133.

Beltman, S., \& Schaeben, M. (2012). Institution-wide peer mentoring: Benefits for mentors. The International Journal of the First Year in Higher Education, 3(2), 33-44.

Blankenship, B. T., \& Coleman, M. M. (2009). An examination of "wash-out" and workplace conditions of beginning physical education teachers. Physical Educator, 66(2), 97.

Bollin, G. G. (2007). Preparing teachers for Hispanic immigrant children: A service learning approach. Journal of Latinos and Education, 6(2), 177-189.

Boudreau, J. W., Boswell, W. R., \& Judge, T. A. (2001). Effects of personality on executive career success in the United States and Europe. Journal of Vocational Behavior, 58(1), 53-81.

Bozionelos, N. (2003). Mentoring provided: Relation to mentor's career success, personality, and mentoring received. Journal of Vocational Behavior, 64(1), 24-46.

Catalano, R. F., Berglund, L. M., Ryan, J. A. M., Lonczak, H. S., \& Hawkins, J. D. (2004). Positive youth development in the United States: Research findings on evaluations of positive youth development programs. The ANNALS of the American Academy of Political and Social Science, 591(1), 98-124.

Cervantes, C. M., \& Meaney, K. S. (2013). Examining service-learning literature in physical education teacher education: Recommendations for practice and research. Quest, 65(3), 332-353.

Chun, J., Sosik, J., \& Yun, N. (2012). A longitudinal study of mentor and protégé outcomes in formal mentoring relationships. Journal of Organizational Behavior, 33(1), 1071-1094. 
Collier, C. (2006). 4.2 Models and curricula of physical education teacher education. Handbook of physical education, 386.

Curtner-Smith, M. D. (1996). The impact of an early field experience on preservice physical education teachers' conceptions of teaching. Journal of Teaching in Physical Education, $15,224-250$.

Curtner-Smith, M. D. (1999). The more things change the more they stay the same: Factors influences teachers' interpretations and delivery of national curriculum physical education. Sport, Education and Society, 4(1), 75-97.

Curtner-Smith, M. D. (2001). The occupational socialization of a first-year physical education teacher with a teaching orientation. Sport, Education and Society, 6(1), 81-105.

Curtner-Smith, M. D. (2009). Breaking the cycle of non-teaching physical education teachers: Lessons to be learned from the occupational socialization literature. In L. D. Housner, M. Metzler, P. G. Schempp, \& T. J. Templin (Eds.), Historic traditions and future directions of research on teaching and teacher education in physical education (pp. 221-225). Mogantown, WV: Fitness Information Technology.

Curtner-Smith, M. D., Hastie, P. A., \& Kinchin, G. D. (2008). Influence of occupational socialization on beginning teacahers' interpretation and deliver of Sport Education. Sport, Education \& Society, 13(1), 97-117.

Domangue, E., \& Carson, R. L. (2008). Preparing culturally competent teachers: Servicelearning and physical education teacher education. Journal of Teaching in Physical Education, 27(1), 347-367.

Dondero, G. M. (1997). Mentors: Beacons of hope. Adolescence, 32(128), 881. 
Durlak, J. A., Weissberg, R. P., Pachan, M. (2010). A meta-analysis of after-school programs that seek to promote personal and social skills in children and adolescents. American Journal of Community Psychology, 45(1), 294-309.

Doyle, W. (1990). Themes in teacher education research. In W.R. Houston (Ed.). In Handbook of Research on Teacher Education. (pp. 3-24). New York: Macmillan.

Fagenson, E. A. (1989). The mentor advantage: Perceived career/job experiences of protégés versus non-protégés. Journal of Organizational Behavior, 10(1), 309-320.

Feiman-Nemser, S. (1990). Teacher preparation: Structural and conceptual alternatives. In W.R. Houston, M. Haberman \& J. Sikula (Eds). Handbook of Research on Teacher Education. (pp. 212-233). New York: Macmillan.

Feiman-Nemser, S., \& Remillard, J. (1996). Perspectives on learning to teach. In F. B. Murray (Ed.), The teacher educator's handbook: Building on knowledge base for the preparation of teachers (pp. 63-91). San Francisco, CA: Jossey-Bass.

FitzGerald, K., Dent, B., Seale, S., Kerins, C., \& McElvaney, R. (2008). The critical incident technique: A useful tool for conducting qualitative research. Journal of Dental Education, 72(3), 299-304.

Flory, S. B., \& McCaughtry, N. (2014). The influences of pre-professional socialization on early career physical educators. Journal of Teaching in Physical Education, 33(1), 93-111.

Gaudreault, K., Shiver, V., Kinder, C., \& Guseman, E. (2016). Healthy Pokes: After-school education and mentoring to enhance child health. Journal of Physical Education, Recreation, \& Dance, 38-43.

Ghosh, R., \& Reio Jr., T. G. (2013). Career benefits associated with mentoring for mentors: A meta-analysis. Journal of Vocational Behavior, 83(1), 106-116. 
Glaser, B. (2017). Discovery of grounded theory: Strategies for qualitative research. New York; London: Routledge.

Gil-Gomez, J., Chiva-Bartoll, O., \& Marti-Puig, M. (2015). The impact of service learning on the training of pre-service teachers: Analysis from a physical education subject. European Physical Education Review, 21(4), 467-484.

Gordon, J., Downey, J., \& Bangert, A. (2013). Effects of a school-based mentoring program on school behavior and measures of adolescent connectedness. School Community Journal, 23(2), 227-250.

Graber, K. C. (1991). Studentship in preservice teacher education: A qualitative student of undergraduates in physical education. Research Quarterly for Exercise and Sport, 16(1), $41-51$.

Graber, K. C., Killian, C. M, \& Woods, A. M. (2017). Professional socialization, teacher education programs, and dialectics. In K. Richards \& K. Gaudreault (Eds.) Teacher socialization in physical education: New perspectives (pp. 63-78). New York, NY: Routledge.

Grossman, P. L. (1992). Why models matter: An alternate view on professional growth in teaching. Review of Educational Research, 62, 171-179.

Haggard, D. L., Dougherty, T. W., Turban, D. B., \& Wilbanks, J. E. (2011). Who is a mentor? A review of evolving definitions and implications for research. Journal of Management, $37(1), 280-304$.

Hunt, D. M., \& Michael, C. (1984). Mentorship. Journal of Library Administration, 5(1), 77-95. Jacobi, M. (1991). Mentoring and undergraduate academic success: A literature review. Review of Educational Research, 61(4), 505-532. 
Kagan, D. M. (1992). Professional growth among preservice and beginning teachers. Review of Educational Research, 62, 129-169.

Katz, J., DuBois, M., \& Wigderson, S. (2014). Learning by helping? Undergraduate communication outcomes associated with training or service-learning experiences. Society for the Teaching of Psychology, 41(3), 251-255.

Kaye, C. B. (2010). The complete guide to service learning: Proven, practical ways to engage students in civic responsibility, academic curriculum, and social action. (2 $\left.{ }^{\text {nd }} \mathrm{ed}.\right)$. Minneapolis: Free Spirit Publishing, Inc.

Kram, K. E. (1985). Mentoring at work: Developmental relationships in organizational life. Glenview, IL: Scott, Foresman.

Kram, K. E., \& Isabella, L. A. (1985). Mentoring alternatives: The role of peer relationships in career development. Academy of Management Journal, 28(1), 110-132.

Kahne, J., Nagaoka, J., Brown, A., O’Brien, J., Quinn, T., \& Thiede, K. (2001). Assessing afterschool programs as contexts for youth development. Youth \& Society, 32(4), 421-446.

Koch, T. (2006). Establishing rigour in qualitative research: The decision trail. Journal of Advanced Nursing. 53(1), 91-103.

Lawson, H. A. (1983). Toward a model of teacher socialization in physical education: The subjective warrant, recruitment, and teacher education (part 1). Journal of Teaching in Physical Education, 2(3), 3-16.

Lawson, H. A. (1986). Occupational socialization and the design of teacher education programs. Journal of Teaching in Physical Education, 5(1), 107-116. 
Lawson, H. A. (1989). From rookie to veteran: Workplace conditions in physical education and induction into the profession. In T.J. Templin \& P.G. Schempp (Eds.), Socialization into physical education: Learning to teach (pp. 145-164). Indianapolis, IN: Benchmark.

Lincoln, Y. S., \& Guba, E. G. (1985). Naturalistic inquiry. Beverly Hills, CA: Sage.

Lortie, D.C. (1975). Schoolteacher: A sociological study. Chicago: University of Chicago Press.

Mahoney, J. L., Larson, R. W., \& Eccles, J. S. (Eds.). (2005). Organized activities as contexts of development: Extracurricular activities, after school and community programs. Hillsdale, NJ: Erlbaum.

Merriam, S. B., \& Tisdell, E. (2016). Qualitative research: A guide to design and implementation $\left(4^{\text {th }}\right.$ ed.). San Francisco: Jossey-Bass.

Minor, J. (2002). Incorporating service learning into ESOL programs. TESOL Journal, 11(4), 1014.

O’Bryant, C. P., O’Sullivan, M., \& Raudensky, J. (2000). Socialization of prospective physical education teachers: The story of new blood. Sport, Education \& Society, 5(2), 177-193.

O’Shea, S., Harwood, V., Kervin, L., \& Humphry, N. (2013). Connection, challenge, and change: The narratives of university students mentoring young Indigenous Australians. Mentoring and Tutoring, 21(4), 392-411.

O’Sullivan, M. (1989). Failing gym is like failing lunch or recess: Two beginning teachers' struggle for legitimacy. Journal of Teaching in Physical Education, 8(3), 227-242.

Patton, M. Q. (2015). Qualitative research and methods: Integrating theory and practice; The definitive text of qualitative frameworks and options ( $4^{\text {th }}$ ed.). Thousand Oaks, CA: SAGE Publications, Inc. 
Peralta, L. R., O’Connor, D., Cotton, W. G., \& Bennie, A. (2016). Pre-service physical education teachers' Indigenous knowledge, cultural competency and pedagogy: A service learning intervention. Teaching Education, 27(3), 248-266.

Pike, S., \& Fletcher, T. (2014). A review of research on physical education teacher socialization from 2000-2012. PHEnex Journal, 6(1), 1-17.

Pittman, K., Irby, M., Tolman, J., Yohalem, N., \& Ferber, T. (2003). Preventing problems, promoting development, encouraging engagement: Competing priorities or inseparable goals?. Based upon Pittman, K. \& Irby, M. (1996). Preventing Problems or Promoting Development? Washington, DC: The Forum for Youth Investment, Impact Strategies, Inc. Available online at www.forumfyi.org.

Posner, J. K., \& Vandell, D. L. (1994). Low-income children's after-school care: Are there beneficial effects of after-school programs? Society for Research Child Development, 65(2), 440-456.

Raggins, B. R., \& Cotton, J. L. (1999). Mentor functions and outcomes: A comparison of men and women in formal and informal mentoring relationships. Journal of Applied Psychology, 84(4), 529-550.

Raggins, B. R., \& Scandura, T. A. (1999). Burden or blessing? Expected costs and benefits of being a mentor. Journal of Organizational Behavior, 20(1), 493-509.

Richards, K. A. R. (2015). Role socialization theory: The sociopolitical realities of teaching physical education. European Physical Education Review, 21(3), 379-393.

Richards, K. A. R., \& Templin, T. J. (2011). The influence of a state mandated induction assistance program on the socialization of a beginning physical education teacher. Journal of Teaching in Physical Education, 20, 340-357. 
Richards, K. A. R., Templin, T. J., \& Graber, K. (2014). The socialization of teachers in physical education: Review and recommendations for future works. Kinesiology Review, 3(2), 113-134.

Richards, K. A. R., Gaudreault, K., \& Templin, T. (2014). Understanding the realities of teaching: A seminar series focused on induction. Journal of Physical Education, Recreation, \& Dance, 85(9), 28-35.

Richards, K. A. R., Templin, T., \& Gaudreault, K. (2013). Understanding the realities of school life: Recommendations for the preparation of physical education teachers. Quest, 65(4), $442-457$.

Rogers, T., Marshall, E., \& Tyson, C. A. (2006). Dialogic narratives of literacy, teaching, and schooling: Preparing literacy teachers for diverse settings. Reading Research Quarterly, 41(2), 202-224.

Roth, J. L., Malone, L. M., \& Brooks-Gunn, J. (2010). Does the amount of participation in afterschool programs relate to developmental outcomes? A review of the literature. American Journal of Community Psychology, 45(1), 310-324.

Russell, J., Gaudreault, K., \& Richards, K. A. R. (2016). Doctoral student socialization: Educating stewards of the physical education profession. Quest, 68(4), 439-456.

Schempp, P. G., \& Graber, K. C. (1992). Teacher socialization from a dialectical perspective: Pretraining through induction. Journal of Teaching in Physical Education, 11(4), 329348.

Smith, E. P. (2004, March 23). The role of afterschool settings in positive youth development. Journal of Adolescent Health, 41, 219-220. 
Stran, M., \& Curtner-Smith, M. (2009). Influence of occupational socialization on two preservice teachers' interpretation and delivery of the sport education model. Journal of Teaching in Physical Education, 28(1), 38-53.

Stroot, S. (Ed.) (1993). Socialization into physical education [Monograph]. Journal of Teaching in Physical Education, 12(4), 337-466.

Stroot, S. A., Faucette, N., \& Schwager, S. (1993). In the beginning: The induction of physical educators. Journal of Teaching in Physical Education, 12(4), 375-385.

Stroot, S. A., \& Ko, B. (2006). Teacher socialization and induction. In D. Kirk, M. O'Sullivan, \& D. Macdonald (Eds.), Handbook of Research in Physical Education. (pp. 425-448). Berkeley, CA: Sage Publications.

Szente, J. (2008). Preparing preservice teachers to work with culturally and linguistically diverse children: A service learning experience. Journal of Early Childhood Teacher Education, $29(2), 140-145$.

Tebes, J. K., Feinn, R., Vanderploeg, J. J., Chinman, M. J., Shepard, J., Brabham, T., Genovese, M., \& Connell, C. (2007). Impact of a positive youth development program in urban after-school settings on the prevention of adolescent substance use. Journal of Adolescent Health, 41(1), 239-247.

Templin, T. J., \& Richards, K. A. R. (2014). C. H. McCloy Lecture: Reflections on socialization in physical education: An intergenerational perspective. Research Quarterly for Exercise and Sport, 85(4), 431-445.

Templin, T. J. \& Schempp, P. G. (1989a). Socialization into physical education: Its heritage and hope. In T. J. Templin \& P. G. Schempp (Eds.), Socialization into physical education: Learning to teach (pp. 1-11). Indianapolis, IN: Benchmark. 
Tripp, D. (1993). Critical incidents in teaching: Developing professional judgement. New York; London: Routledge.

Trost, S. G., Rosenkranz, R. R., \& Dzewaltowski, D. (2008). Physical activity levels among children attending after-school programs. Medicine \& Science in Sports \& Exercise, 40(4), 622-629.

U.S. Department of Human Health Services (USDHHS). (2016, April 20). Objectives: HealthyPeople2020. Retrieved from Healthy People 2020: https://www.healthypeople.gov/

Vandell, D. L., Reisner, E. R., \& Pierce, K. M. (2007). Outcomes linked to high-quality afterschool programs: Longitudinal findings from the study of promising afterschool programs. Philadelphia: Policy Studies Associates. Retrieved from https://www.naesp.org/sites/default/files/resources/1/A_New_Day_for_Learning_Resou rces/Making_the_Case/Outcomes_Linked_to_High-Quality_Afterschool_Programs.pdf

Vandell, D. L., Reisner, E. R., Pierce, K. M., Brown, B. B., Lee, D., Bolt, D., \& Pechman, E. M. (2006). The study of promising after-school programs: Examination of longer term outcomes after two years of program experiences. Retrieved from http://www.wcer.wisc.edu/childcare/pdf/pp/year_3_report_final.pdf.

Veenman, S. (1984). Perceived problems of beginning teachers. Review of Educational Research, 54(2), 143-178.

Wang, Y., \& Jackson, G. (2005). Forms and dimensions of civic involvement. Michigan Journal of Community Service Learning, 12(1), 29-48.

Weis, R. (2004). Using an undergraduate human-service practicum to promote unified psychology. Teaching of Psychology, 31(1), 43-46. 
Wilkinson, S., Harvey, W. J., Bloom, G. A., Joober, R., \& Grizenko, N. (2013). Student teacher experiences in a service-learning project for children with attention-deficit hyperactivity disorder. Physical Education and Sport Pedagogy, 18(5), 475-491.

Williams, J. A., \& Williamson, K. M. (1998). The socialization strategies of first-year physical education teachers: Conflict and concessions. Physical Educator, 55(2), 78-88.

Zeichner, K. (1983). Alternative paradigms of teacher education. Journal of Teacher Education, $34(3), 3-9$. 


\section{APPENDIX A: INTERVIEW GUIDES}

Interview \#1 (K-12 Experiences)

1. Tell me about your experiences as a student in K-12 PE.

a. Tell me about your PE teachers (what did they look like, act like, etc).

2. When did you know you wanted to be a PE teacher?

a. Tell me about how you knew, when, etc.

3. Why do you want to be a PE teacher?

4. What qualities do you think good teachers need to have?

5. What type of person do you think a teacher needs to be?

6. What qualities do you feel you possess that make teaching a good fit for you as a person?

7. What do you believe is the purpose of PE?

8. How do you see your K-12 experiences impacting your views of PE? Of PE teachers?

Interview \#2 (PETE Program)

1. Tell me about your experiences in the PETE program- start at the beginning and take me up to now.

2. Tell me how you perceive the program as relevant to becoming a successful physical educator.

3. Tell me what specific parts of the program are the most valuable for you as a teacher.

4. Talk to me about how your previous values and beliefs about PE have been either confirmed or impacted by your time in the PETE program.

5. Talk to me about how the professors within the program have impacted you as a teacher. 
6. Talk to me about your cohort/peers, how have they impacted you as a teacher.

7. How have cooperating teachers you have worked with impacted you as a teacher?

8. Tell me about your interests in teaching and coaching.

9. How do you think the practicum experiences (Lab $1 \& 2$ ) have impacted you as a teacher?

10. What do you think is your greatest strength as a teacher right now?

11. Is there anything else you want to share?

Interview \#3 (After-school Program Experiences)

1. Tell me about your experience in the ASP. Start at the beginning and take me up to now.

2. How have your experiences with the ASP impacted you as a teacher?

3. How has working in the ASP impacted your ideas about PE?

4. Tell me about your experiences working with the at-risk children in the ASP.

a. How do you see these impacting your views about teaching?

b. How do you see these impacting your views about physical education?

5. If you could only say one thing about working in the ASP for pre-service teachers, what would you say?

Interview \#4 (Mentoring Experiences)

1. What does mentoring mean to you?

2. Talk to me about your experiences with mentoring in the ASP.

a. What was it like for you?

b. What is the best thing about mentoring? 
c. What is the "worst" or hardest thing about mentoring?

3. Tell me about your mentee(s).

4. Tell me about someone who was a "mentor" like figure to you as a child/youth.

5. How have your experiences with mentoring impacted you as a teacher?

6. How has mentoring impacted your ideas about PE?

7. How has it impacted your thoughts about at-risk children?

8. Tell me about a time while mentoring that you faced a challenging situation.

9. Talk to me about a time that was satisfying for you while mentoring.

10. Tell me the most significant thing that you learned or took away from your mentoring experience.

11. If you had to tell someone outside of PETE/K\&H about mentoring in the ASP, what would you tell them? 


\section{APPENDIX B: CRITICAL INCIDENT PROMPTS}

Critical Incident Account \#1

Think of a time during elementary/middle/high school when something in PE (or related to PE) happened that was very critical/significant. This could be something that was really awesome and was a positive experience for you OR this could also be something that happened that made a huge impact on you because it was a bad experience.

Critical Incident Account \#2

Think of a time when something happened during your time in the PETE program that made a significant impact on you as a teacher. This could be a really positive incident or a really negative one.

Critical Incident Account \#3

Think of a time when something happened during the ASP that made a significant impact on you as a teacher. This could be a really positive incident or a really negative one.

Critical Incident Account \#4

Think of a time when something happened while mentoring at the ASP that made a significant impact on you as a teacher. This could be a really positive incident or a really negative one. 